\title{
EFFECTS OF STREET TREE SHADE ON ASPHALT CONCRETE PAVEMENT PERFORMANCE
}

\author{
By E. Gregory McPherson ${ }^{1}$ and J ules Muchnick ${ }^{2}$
}

\begin{abstract}
Forty-eight street segments were paired into 24 highand low-shade pairs in Modesto, California, U.S. Field data were collected to calculate a Pavement Condition Index (PCI) and Tree Shade Index (TSI) for each segment. Statistical analyses found that greater PCI was associated with greater TSI, indicating that tree shade was partially responsible for reduced pavement fatigue cracking, rutting, shoving, and other distress. Using observed relations between PCI and TSI, an unshaded street segment required 6 slurry seals over 30 years, while an identical one planted with 12 crape myrtles (Lagerstroemia indica, $4.4 \mathrm{~m}$ [14 ft] crown diameter) required 5 slurry seals, and one with 6 Chinese hackberry (Celtis sinensis, $13.7 \mathrm{~m}$ [45 ft] crown diameter) required 2.5 slurry seals. Shade from the large hackberries was projected to save $\$ 7.13 / \mathrm{m}^{2}$ $\left(\$ 0.66 / \mathrm{ft}^{2}\right)$ over the 30-year period compared to the unshaded street.

Key Words. Avoided repaving costs; pavement distress; tree benefits; urban heat island.
\end{abstract}

Street tree populations provide many benefits that in total often exceed their management costs (McPherson et al. 1999; Maco and McPherson 2002). Yet street trees are often perceived as liabilities due to litter drop, root damage to sidewalks, and visibility and security problems created by blocking signs and lighting (Lohr et al. 2004). Attitudes that trees are "bad." limited municipal funds, and competing interests make justifying budgets for tree maintenance difficult.

One benefit of urban trees that has not been examined is the relationship between tree shade and pavement performance. Performance relates to a pavement's ability to maintain its design standards and intended functional and structural condition (Scholtz and Brown 1996). Asphalt pavements are a combination of an aggregate, known as the filler, and asphalt cement, referred to as the binder, varying in both thickness and type (Wallace and Martin 1967). A typical flexible pavement consists of several layers-a hot-rolled asphalt wearing surface supported by a combination of one or several granular base courses on a subgrade foundation of unbound aggregates and compacted soils (Hunter 1994).

Asphalt concrete pavements on streets and parking lots occupy about $30 \%$ of the land in our cities and can be characterized as miniature heat islands and sources of motor vehicle pollutants (Scott et al. 1999; Pomerantz et al. 2000b). By attenuating irradiance and lowering air and surface temperatures, street trees have a moderating effect on climatic conditions that affect pavement performance (Heisler 1977). "Oasis effects" of $5^{\circ} \mathrm{C}$ to $7^{\circ} \mathrm{C}\left(9^{\circ} \mathrm{F}\right.$ to $\left.12.6^{\circ} \mathrm{F}\right)$ have been measured as a result of direct shading of the ground surface and transpiration of water through leaves (Asaeda et al. 1996).

As pavement temperatures rise, volatilization of the asphalt binder and oxidation lead to a progressive hardening of the pavement, which results in increased fatigue cracking and reduced durability (Harvey et al. 2000; Srivastava and van Rooijen 2000). Higher surface temperatures make the pavement more prone to rutting (Pomerantz et al. 2000a). Better pavement performance due to extensive tree shade could translate into a less frequent repaving schedule and cost savings. The street superintendent in Modesto, California, U.S. estimated that repaving could be deferred 10 years on a well-shaded street and potentially up to 25 years on heavily shaded streets (Brusca 1998).

The goal of this study was to determine whether tree shade produces a beneficial effect on pavement performance. We compared pavement condition data from similar streets receiving different amounts of tree shade. Because a longer-lived pavement can be an economic asset, we used empirically derived relationships between tree shade and pavement condition to project potential savings for two identical street segments, one shaded by large trees and one by small trees.

\section{METHODS \\ Study Area}

The city of Modesto is located approximately $124 \mathrm{~km}(77$ mi) south of Sacramento in California's San Joaquin Valley. At an elevation of $26.5 \mathrm{~m}(87 \mathrm{ft})$ above sea level, the climate is characterized by hot, dry summers and cool, wet winters. Average annual rainfall is $280 \mathrm{~mm}$ (11 in.) and most occurs from November to March. Summer temperatures commonly are above $29^{\circ} \mathrm{C}\left(85^{\circ} \mathrm{F}\right)$ and may exceed $38^{\circ} \mathrm{C}\left(100^{\circ} \mathrm{F}\right)$ but rarely exceed $41^{\circ} \mathrm{C}\left(105^{\circ} \mathrm{F}\right)$ (Weatherbase 2001). Winter temperatures commonly fall below $0^{\circ} \mathrm{C}\left(32^{\circ} \mathrm{F}\right)$ but rarely are lower than $-4^{\circ} \mathrm{C}\left(25^{\circ} \mathrm{F}\right)$. Modesto's street system includes 925 street $\mathrm{km}$ ( $575 \mathrm{mi}$, or about 1,130 lane miles) and about $60 \%$ of streets are residential (City of Modesto 2001). The city uses the Metropolitan Transportation Commission's (MTC) Pavement Management System (PMS) to help evaluate the condition of its pavements. Inspection of collector and arterial streets occurs every 2 years, while 
residential streets are inspected every 4 to 6 years, depending on budget constraints. 1996 was the last year that residential streets were inspected, and over $70 \%$ of streets were in "good to very good/excellent" condition (City of Modesto 2001).

\section{Sampling}

Data from Modesto's street tree inventory, geographic information system, and street services records were used to identify street segments that met the following requirements: (1) residential streets constructed in the 1950s and 1960s, (2) majority of originally planted trees still present, and (3) segment pairs that had similar maintenance histories. Forty paired segments were sampled. Each pair consisted of identically sized segments (93 to $418 \mathrm{~m}^{2}$ [1,000 to $\left.4,500 \mathrm{ft}^{2}\right]$ ) that came from the same roadway. The dimensions of a typical segment were $38.1 \times 10.7 \mathrm{~m}(125 \times$ $35 \mathrm{ft}$ ). Visual estimates of tree canopy size were used to pair low-shade control segments and nearby high-shade treatment segments.

An additional 16 segments (eight pairs) could not be paired with another from the same street but were paired with segments from nearby roadways. An asphalt core was extracted and material testing performed on one core from each of these segments (16 cores) to ensure that material properties of the matched segments were similar.

Kleinfelder, Inc. collected one $10 \mathrm{~cm}$ (4 in.) core sample per street segment and conducted four tests that assessed asphalt content, air-void content, and gradation characteristics. Segments that met the following criteria were considered analogous and were included in the sample:

1. No more than 3\% difference in air-void content between segments.

2. Segments with multiple lifts (layers) had similar ratios of the top lift thickness to the underlying lift thickness.

3. Segment construction dates were no more than 4 years apart.

4. Mixes had similar aggregate gradations.

Eight segments met these criteria and were matched into four pairs. The entire sample consisted of these four pairs plus 20 pairs that had segments from the same street, for a total of 24 pairs containing 48 segments.

\section{Data Collection}

Tree, site, and pavement condition data were collected for each sampling segment during summer 2001. Tree data collected included species, age (planting date from the inventory database), dbh (diameter at breast height), crown diameter, tree height, bole height (ground to crown bottom), shape (silhouette of entire tree, recorded as either ellipsoid or paraboloid), crown density (at one tree-length away compared the observed crown density with percentages shown on the crown density card to the nearest 5 percent class), and curb distance (setback distance of tree to curb).

Site data included sampling unit dimensions (segment length and width), street orientation (recorded as E/W or N/ $S$ ), and distance from the relative origin (corner of the segment). A sketch of each segment recorded the corner marked as the relative origin and tree coordinates.

Pavement condition was assessed using protocols defined by the Metropolitan Transportation Commission (MTC 1986). Pavement data included

- street name;

- segment unit number;

- type of distress, assessed by visual estimation: (1) alligator cracking, (2) block cracking, (3) distortions, (4) longitudinal and transverse cracking, (5) patching/ utility cut patching, 6) rutting and depressions, and (7) weathering;

- amount of distress (distance measured with measuring wheel); and

- severity of distress (measured in levels of low, medium, or high).

$\mathrm{PCl}$ and TSI Calculations and Statistical Analysis Two parameters, Pavement Condition Index (PCI) and Tree Shade Index (TSI), were calculated based on measurements and observations recorded for each street segment. PCI was calculated based on pavement distress types, amounts, and severities using MTC's standard six-step protocol (Smith 2001).

1. The inspection unit was inspected using a distress identification guide, and the approximate amount of each distress type/severity combination was recorded as a percentage by dividing the distress type/severity combination quantities by the total area of the segment and multiplying by 100 .

2. The deduct values for each distress type/severity combination were determined from deduct curves in the appendices. The PCI procedure uses a set of "deduct curves" to calculate the numerical impact of each distress type/severity combination on the overall PCI. They are called deduct curves because the value determined from the curves is deducted from the maximum score of 100 .

3. The number of distress type/severity combinations with deduct values greater than 5 were counted. This is the q-value and was used later in the calculation to correct the curves because research found that if occurrences of small deduct values were included, the final value would be too small, or over-corrected.

4. The total deduct value was computed by summing all deduct values for the distress type/severity combinations.

5. When multiple distress type/severity combinations are present, the deduct units must be corrected because research found that as more distress type/severity 
combinations occur in the same inspection unit, they have less and less impact. To account for this nonlinearity, total deduct value and the q-value were used with correction curves in the appendices to determine the corrected deduct value.

6. The corrected deduct value was subtracted from 100 to determine the inspection unit PCI.

The PCI scale ranged from 100 for a new, well-constructed pavement to 0 for a pavement beyond repair.

TSI was calculated based on tree dimensions and crown density, tree location, foliation period, and segment size. These data were used with the Shadow Pattern Simulation (SPS) computer model to calculate the average amount of shade a segment received as a percentage of maximum possible shade during the March through October foliation period (McPherson et al. 1985). SPS used site and tree data to calculate the percentage of surface area (SA) shaded for each half-hour, where SF is the fraction of total surface area shaded:

$$
\mathrm{SF}_{(\mathrm{i})}=\mathrm{SA}\left(1-\mathrm{SC}_{\mathrm{t}}\right)
$$

where (SC), or tree shading coefficient, corresponded to the percentage of available solar radiation transmitted through the tree crown at time $\mathrm{t}_{(\mathrm{i})}$. Steps to calculate TSI were

1. SPS simulations were conducted for the 15th of every month to develop a $\mathrm{SF}_{\mathrm{h}}$ for each daylight hour.

2. $\mathrm{SF}_{\mathrm{h}}$ were averaged for the entire day to derive the average Daily Shade Factor (DSF).

3. DSFs were averaged for March-October to derive an average Annual Shade Factor (ASF) for each segment.

4. ASFs were multiplied by 100 to compute segment's TSI value.

The TSI scale ranged from 100 for pavement in complete shade to 0 for pavement receiving no shade.

Descriptive statistics were employed to analyze the relationship between TSI and PCI. The t-test, a Wilcoxon signed rank test, or a signed test were used to determine whether the high-shade segments had higher PCI values than the low-shade ones, depending on whether the data were normally distributed. Regression methods were used to assess the association between the difference in shade level and difference in pavement condition. Regression analyses were performed using different dependent variables to determine whether any single pavement distress was strongly associated with tree shade.

\section{Economic Analysis}

Pavement maintenance strategies recognize the economic importance of maintaining optimum levels of pavement condition. For example, in Modesto the average lifespan of a residential street is 40 years, and preventive maintenance keeps streets safe and extends their lifespan (Buss 2002). Pavements that maintain better performance conditions last longer and ultimately require less maintenance. In addition, as pavement conditions deteriorate, maintenance and repair costs become increasingly more expensive (Smith 1994). As with trees, pavements maintained in good condition require less expensive maintenance and repair strategies.

Scenario. A hypothetical scenario was created to demonstrate how the amount of tree shade influences preventive maintenance expenditures over a 30-year period. Preventive maintenance includes treatments such as slurry seals and thin overlays applied to reduce the rate of pavement deterioration.

The scenario was based on the following premise: in Modesto, California, two residential street segments were identical in composition and exposed to identical conditions. They were made of asphalt concrete, had east-west facing orientations, and were $38.1 \mathrm{~m}(125 \mathrm{ft})$ long and $10.7 \mathrm{~m}(35 \mathrm{ft})$ wide, measuring $406.5 \mathrm{~m}^{2}\left(4,375 \mathrm{ft}^{2}\right)$. Only the species and number of trees planted differed. One pavement, known as Crape Myrtle Drive, was planted with 12 crape myrtle trees (Lagerstroemia indica) equally spaced at $7.62 \mathrm{~m}(25 \mathrm{ft}$.) intervals (Figure 1). The other pavement, Hackberry Drive, was planted with six Chinese hackberry trees (Celtis sinensis) equally spaced at $15.24 \mathrm{~m}(50 \mathrm{ft})$ intervals. Trees on both streets were planted at the time of pavement construction and set back $3.2 \mathrm{~m}(10.5 \mathrm{ft})$ from the curb.

Thirty years after the construction, Modesto's Department of Public Works resurfaced both roads so that their

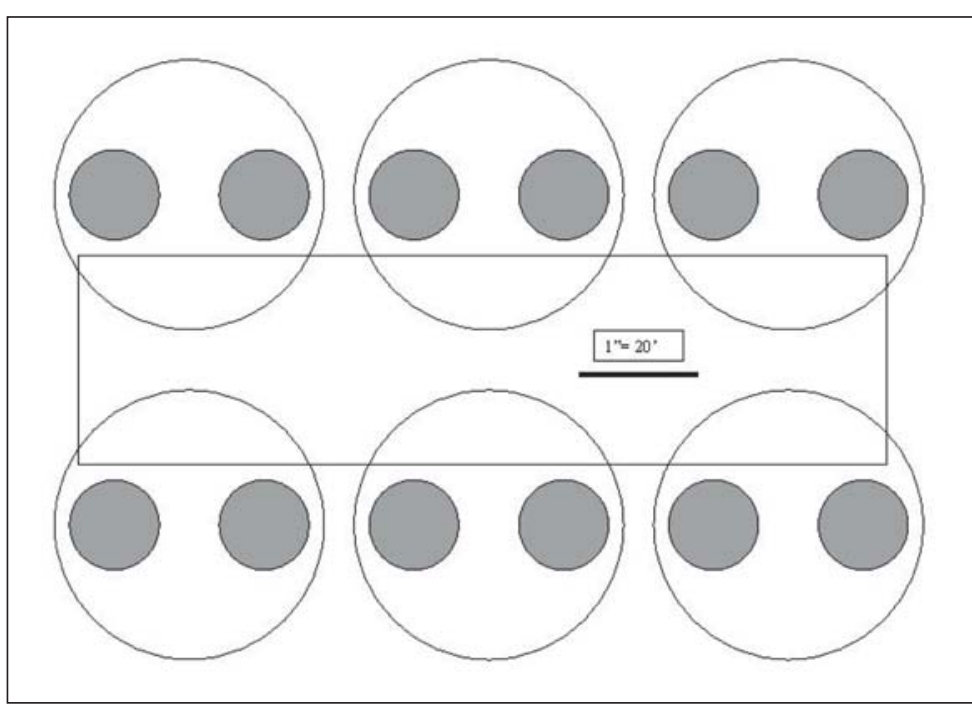

Figure 1. Two scenarios showing locations and sizes of 12 crape myrtle (shaded circles) and 6 hackberry (unshaded circles) street trees 30 years after planting. The trees were assumed to be planted along identical street segments, each

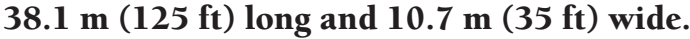


PCIs equaled 100. The new pavements were approximately identical to the older ones and to each other with the only difference between them being the amount of shade they received from the now-mature, 30-year-old street trees.

Estimating TSI and PCI Values. Tree dimensions were estimated using tree growth equations developed by Peper et al. (2001) (Table 1). TSI values were calculated using SPS, with assumed shading coefficients of $15 \%$ and $25 \%$ for the hackberries and crape myrtles, respectively (McPherson 1984).

Deterioration curves were developed to depict relations between PCI and TCI as observed in Modesto. An exponential decrease model was fit to the PCI data:

$$
\operatorname{Ln}(\mathrm{PCI})=\text { years } *\left(\mathrm{~b}_{1}+\mathrm{b}_{2} * \mathrm{TSI}\right)
$$

where $b_{1}(-0.0631331)$ and $b_{2}(0.000803095)$ were regression coefficients. The model was fit without an intercept term so that the PCI immediately upon resurfacing was estimated as 100 .

Table 1. Tree dimensions at 30 years after planting.

\begin{tabular}{lllll}
\hline Tree species & Dbh $(\mathrm{cm} / \mathrm{in})$. & Height $(\mathrm{m} / \mathrm{ft})$ & Crown height $(\mathrm{m} / \mathrm{ft})$ & Crown diameter $(\mathrm{m} / \mathrm{ft})$ \\
\hline Crape myrtle & $14.8(6.8)$ & $5.3(17.4)$ & $3.6(11.8)$ & $4.4(14.4)$ \\
Hackberry & $49.2(19.4)$ & $14.6(47.9)$ & $11.6(38.0)$ & $13.7(44.9)$ \\
\hline
\end{tabular}

\section{RESULTS}

A scatter plot showing the differences in TSI between control and shaded segments and corresponding differences for PCI indicated that the relationship between PCI and TSI was consistent with the hypothesis that tree shade has a beneficial effect on pavement performance (Figure 2). Data were normally distributed (the Shapiro-Wilks test was insignificant, $P=$ 0.41 ). The $t$-test statistic was significant $(t=4.80, P<0.0001)$, indicating a systematic difference between the paired comparisons. In addition, the test statistic was positive, signifying that greater tree shade was associated with greater PCI.

Regression was significant $(P=0.0001)$, indicating that the relationship between PCI and TSI was not likely to have happened by chance. The regression coefficient was positive $(0.544$, standard error of 0.117 ), signifying that the relationship was direct instead of inverse. The $R^{2}$ value indicates that $49 \%$ of the variation in PCI was accounted for by the variation in TSI, while 51\% was accounted for by random variability. The $R^{2}$ describes how much variability in the pairwise difference in pavement condition could be explained regarding the pairwise difference in shade index. Variability was strictly controlled within pairs, but it was not as tightly controlled among pairs. Variability factors that could have an impact include the age of the pavement, traffic volume, and proportion of trucks on the road. This $R^{2}$ was based on a model through the origin because if the difference in TSI was 0 , the choice of which segment was the control and which was shaded becomes arbitrary.

The regression equation was

$$
\Delta \mathrm{PCI}=(0.544 \pm 0.117) \Delta \mathrm{TSI} .
$$

From this equation, differences in the pavement condition index can be predicted from differences in tree shade index. For example, if the TSI was increased by $20 \%(\Delta \mathrm{TSI}=20)$, then PCI increased $10.9 \% \pm 0.117$. A $95 \%$ confidence interval for this example was

$$
\left(\mathrm{b} \pm 2 \mathrm{~s}_{\mathrm{b}}\right) \Delta_{\mathrm{o}}=(0.544 \pm 2(.117))(20),
$$

where $\Delta_{\mathrm{o}}$ was the hypothetical change in tree shade index, b was the regression coefficient, and $s_{b}$ was the standard error of the coefficient. Therefore, with 95\% confidence, the change in $\mathrm{PCI}$ associated with a 20\% increase in TSI was between 6.20 and 15.56

Subsequent analyses did not find strong relations between any one distress and shade. All three tests of location were significant for alligator cracking, and the test statistics were negative, implying that there was a significant, inverse relationship between shading and road damage (the more shade, the less damage). Results of the Wilcoxon signed rank test found

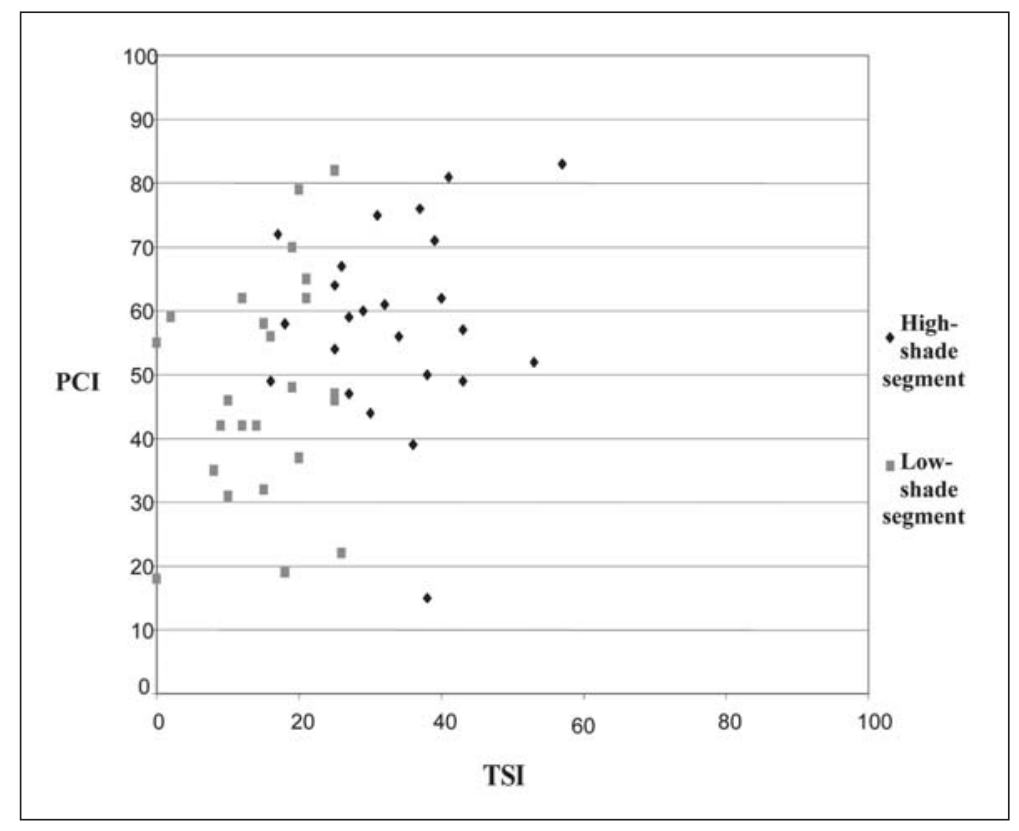

Figure 2. Pavement Condition Index (PCI) versus Trees Shade Index (TSI) scatter plot for $\mathbf{4 8}$ pavement segments. 
that the median difference value was -0.017 , while the mean was -0.039 . Regression analysis showed a mild inverse relationship between TSI and alligator cracking $\left(R^{2}\right.$ was $\left.-0.002, P=0.0358\right)$. Analysis for the other distresses (i.e., block cracking, distortions, longitudinal/transverse cracking, patching/utility patching, rutting/depressions, and weathering) found that the data were not normally distributed and, therefore, regression analysis was not conducted.

\section{Economic Analysis}

Thirty years after planting, the calculated TSI values were 41 for Hackberry Drive and 9 for Crape Myrtle Drive. Using these TSI values, as well as 0 (no street tree shade), and assuming these values remained constant, predicted PCIs were plotted for a 30-year period (Figure 3).

Pavement management systems often determine a set of "break points" to effectively time maintenance activities. These points represent critical PCI values, signifying the need for pavement repair before conditions deteriorate to a level where a more expensive strategy is required. This scenario used a break point of 70 as an indicator for the need to resurface. It was assumed that resurfacing was performed with a slurry seal application, a typical and cost-effective maintenance strategy. It was also assumed that with each slurry seal treatment, the PCI value immediately increased to 100 . By applying this break point to the graph, maintaining a PCI of at least 70 over 30 years on the unshaded street required a slurry seal application every 5 years, or approximately six slurry seals within 30 years. Maintaining a PCI of at least 70 on Crape Myrtle and Hackberry drives required slurry sealing every 6 and 12 years, respectively, or 5 and 2.5 applications within 30 years (Table 2).

Assuming slurry seal applications cost $\$ 2.05 / \mathrm{m}^{2}(\$ 0.19$ / $\mathrm{ft}^{2}$ ) (Buus 2002), and this price remained fixed over the 30year period, one application cost $\$ 829$ per street segment. The cost of maintaining a PCI of 70 was $\$ 4,971$ on the unshaded street segment, $\$ 4,142$ on Crape Myrtle Drive, and $\$ 2,071$ on Hackberry Drive (Table 2). Thus, shade on Hackberry Drive is projected to reduce costs for repaving by $\$ 2,900(58 \%)$ over the 30 -year period, or $\$ 7.13 / \mathrm{m}^{2}$ $\left(\$ 0.66 / \mathrm{ft}^{2}\right)$ compared to the unshaded street. Shade from

Table 2. Number of slurry seals required over 30 years, total costs, savings because of the need for fewer slurry seals, and savings per unit pavement surface for shaded compared to unshaded street segments (area $=406.5 \mathrm{~m}^{2}\left[4,375 \mathrm{ft}^{2}\right]$ ).

\begin{tabular}{llllll}
\hline Scenario & Slurry seals & Total cost $(\$)$ & Savings $(\$)$ & Savings $\left(\$ / \mathrm{m}^{2}\right)$ & Savings $\left(\$ / \mathrm{ft}^{2}\right)$ \\
\hline Unshaded & 6 & 4,971 & & & \\
Crape myrtle & 5 & 4,142 & 829 & 2.04 & 0.19 \\
Hackberry & 2.5 & 2,071 & 2,900 & 7.13 & 0.66 \\
\hline
\end{tabular}

the smaller crape myrtles is projected to save $\$ 829$ (17\%).

The benefits from shade on Hackberry Drive compared to Crape Myrtle Drive illustrate the value of larger-stature trees. Projected savings from the larger hackberries exceeded savings from the crape myrtles by $\$ 2,071$. Also, the need for fewer, larger-stature trees would reduce tree planting costs by $50 \%$. While this analysis does not include a potential higher tree care cost for the hackberry trees, it also does not consider greater environmental and property value benefits from the larger trees (McPherson 2003).

\section{Limitations and Future Research}

The scope of this study extended only to residential asphalt concrete streets "typical" of those in the sample. The complex relationships among factors that affect pavement performance, such as environmental conditions, material composition, traffic loads, and the type/technique of preservation methods, are not well understood, and their confounding effects are not well quantified. A change in any one of these factors may considerably affect the relationships uncovered in this investigation. Results, therefore, are site specific and have limited applicability. In addition, the sample was comprised of 40- to 60-year-old streets that were maintained by surface preservation strategies, which limits the applicability of the results primarily to overlays and resurfacing treatments.

Because the behavior and performance of Modesto street segments were used to create the deterioration curves, any changes 
to them may affect the curves that were created and the economic implications that resulted. Therefore, the savings found here should not be extrapolated to other types of resurfacing treatments or to pavements in different climatic environments. Another limiting assumption is that the PCI returns to 100 after every resurfacing and follows the same deterioration curve downward. In reality, PCI may not return to 100 each time, and microdefects below the surface layer may cause the PCI to descend more sharply than assumed here. The hypothetical example in this paper did not incorporate variability in tree growth, survival, and management found in the real world. Including these sources of variability could alter the results considerably.

Relations between pavement condition and tree shade merit further investigation. Controlled laboratory experiments could lead to a comprehensive understanding of the relationship between tree shade and AC pavement performance. For example, experiments are needed that test identically constructed AC pavements during exposure to different controlled temperature and shade regimes. PCI and TCI calculations may be improved if pavement distresses not affected by tree shade were eliminated (e.g., utility cut patching) and data are used only when air temperature and solar radiation are most intense (e.g., May through September). Further research is needed to refine existing pavement performance models and develop new ones based on both mechanistic and empirical data. Current models are primarily traffic related, focusing only on structural fatigue, or failing to incorporate climate information. The capability of new models to accurately predict effects of tree shade on distresses, such as cracking, rutting, and roughness, should be studied.

Benefits of reducing pavement temperatures by means other than tree shade have been reported (Pomerantz et al. 1997; Akbari and Rosenfeld 2000; Pomerantz et al. 2000b). Benefits include (1) the reduction of volatile asphalt fume emissions, due to a diminished need for asphalt production for pavement repairs, and (2) the ability to use a cheaper grade of asphalt in place of one that is modified, and therefore more expensive, in pavements typically exposed to extreme temperature and solar radiation. Examining and quantifying tree shade's role in the production of these benefits would engender a more comprehensive urban forest benefit-cost analysis.

\section{CONCLUSION}

Effective allocation of limited street tree and pavement management funds requires a comprehensive understanding of their costs and benefits. Although benefits of our urban forests have been shown to outweigh their costs, street trees are still often regarded as liabilities. This study identified a previously unquantified benefit of street trees, their effect on pavement performance.

As the cost of constructing new pavements increases, the need to protect current investments grows. Better pavement performance translates into reduced maintenance and repair costs, and results in decreased total life cycle costs. This study found a correlation between tree shade and better pavement performance. It also demonstrated the economic benefits of increased pavement durability and reduced maintenance costs associated with increased tree shade.

Although our results are limited to a select group of pavements in a specific location, they are significant enough to warrant further investigation. A comprehensive understanding of the benefits of tree shade on pavement performance will allay perceptions of street trees as liabilities and help to justify the retention of healthy urban forests.

\section{LITERATURE CITED}

Akbari, H., and A.H. Rosenfeld. 2000. Cool communities, pp. 305-308. In Zumerchik, J. (Ed.). Macmillan Encyclopedia of Energy. Macmillan Reference USA, New York, NY.

Asaeda, T., V. Ca, and A. Wake. 1996. Heat storage of pavement and its effect on the lower atmosphere. Atmos. Environ. 30:413-427.

Brusca, J. 1998. Street Superintendent, City of Modesto, California. Personal communication with Greg McPherson 17 Nov. 1998.

Buus, Norman. 2002. Assistant Civil Engineer, City of Modesto, California. Personal communication with Jules Muchnick 8 Oct. 2002.

City of Modesto. 2001. City of Modesto Pavement Management System Overview. www.ci.modesto.ca.us/ etd/reports/pdf/PMS_Overview_Report.pdf [accessed 10/17/20].

Harvey, J., A. Chong, and J. Roesler. 2000. Climate regions for mechanistic-empirical pavement design in California and expected effects on performance. Draft Report for California Department of Transportation. University of California at Berkeley Pavement Research Center. www.its.berkeley.edu/pavementresearch/ Publications.htm [accessed 3/3/01].

Heisler, G.M. 1977. Trees modify metropolitan climate and noise. J. Arboric. 3:201-207.

Hunter, R. 1994. Bituminous Mixtures in Road Construction. Thomas Telford Services Ltd., London. UK. 454 pp.

Lohr, V.I., C.H. Pearson-Mims, J. Tarnai, and D.A. Dillman. 2004. How urban residents rate and rank benefits and problems associated with trees in cities. J. Arboric. 30:28-37.

Maco, S.E., and E.G. McPherson. 2002. Assessing canopy cover over streets and sidewalks in street tree populations. J. Arboric. 28:270-276.

McPherson, E.G. 2003. A benefit-cost analysis of ten street tree species in Modesto, California, U.S. J. Arboric. 29:1-8. 
(Ed.). 1984. Energy-Conserving Site Design. American Society of Landscape Architects, Washington, DC. 326 pp.

McPherson, E.G., R.A Rowntree, and R. Brown. 1985. Simulating tree shadow patterns for building energy analysis, pp. 378-382. In Wilson, A.T., and W. Glennie (Eds.). Solar 85 Conference Proceedings. 16-20 Oct. 1985, Raleigh, NC. American Solar Energy Society, Boulder, CO.

Metropolitan Transportation Commission (MTC).1986. Pavement Condition Index Distress Identification Manual for Asphalt and Surface Treatment Pavements, Second Edition. Metropolitan Transportation Commission, Oakland, CA. 35 pp.

Peper, P.J., E.G. McPherson, and S.M. Mori, 2001. Equations for predicting diameter, height, crown width, and leaf area of San Joaquin Valley street trees. J. Arboric. 27:306-317.

Pomerantz, M., H. Akbari and J.T. Harvey. 2000a. Durability and Visibility of Cooler Reflective Pavements. University of California and Lawrence Berkeley National Laboratory. LBNL-43443. 61 pp.

Pomerantz, M., B. Pon, H. Akbari, and S.C. Chang. 2000b. The Effect of Pavements' Temperatures on Air Temperatures in Large Cities. Heat Island Group. LBNL43442. Lawrence Berkeley National Laboratory, Berkeley, CA. 20 pp.

Pomerantz, M., H. Akbari, C. Chen, H. Taha, and A.H. Rosenfeld, 1997. Paving materials for heat island mitigation. LBL-38074. U.S. Department of Energy, Washington DC, and Earnest Orlando Lawrence National Laboratory, Berkeley, CA. 19 pp.

Scholtz, T.V., and S.F. Brown. 1996. Factors affecting the durability of bituminous paving mixtures, pp. 173-190. In Cabrera, J.G., and J. R. Dixon (Eds.). Performance and Durability of Bituminous Materials. E \& FN Spon, London, UK.
Scott, K.I., J.R. Simpson, and E.G. McPherson. 1999. Effects of tree cover on parking lot microclimate and vehicle emissions. J. Arboric. 23:129-142.

Smith, R.E. 1994. Pavement/Road Surface Management Overview. Stone Review, National Stone Association, Washington, DC.

Smith, R.E. 2001. Condition Assessment and PCI Calculation for the MTC PMS. Texas A\&M University, College Station, TX. 50 pp.

Srivastava, A., and R. van Rooijen. 2000. Bitumen performance in hot and arid climates. Prepared for the Innovative Road Rehabilitation and Recycling Technologies Pavement Seminar. http://docs. vircomnet.com/mobility/urban_mobility_vc/ paper_for_jordan.htm [accessed 2/2/02] .

Wallace, H.A., and J.R. Martin. 1967. Asphalt Pavement Engineering. McGraw-Hill, San Francisco, CA. 351 pp.

Weatherbase. 2001. Weatherbase Home Page. www.weatherbase.com [accessed 11/6/01].

Acknowledgments. We thank Norm Buus (assistant civil engineer, City of Modesto) for providing technical assistance and information on pavement maintenance histories. Kleinfelder Inc. generously allowed us to use their laboratory for core testing. Dr. James Simpson (U.S. Forest Service) assisted with calculating TSIs. Drs. John Harvey, John Bollander, and Larry Costello at the University of California, Davis, provided valuable input throughout the study.

This article was written and prepared by U.S. government employees on official time and it is, therefore, in the public domain and not subject to copyright.

1,2USDA Forest Service, Pacific Southwest Research Station Center for Urban Forest Research

clo Department of Plant Science, MS-6

One Shields Avenue

University of California

Davis CA, 95616, U.S.

Corresponding author: E. Gregory McPherson. 
Résumé. Quanrante-huit segments de rues ont été appariés au sein de 24 paires d'ombrage faible et élevé, et ce au sein de la ville de Modesto en Californie. Des données ont été récoltées sur le terrain afin de calculer un index d'état du pavage (IEP) et un index d'ombrage par les arbres (IOA) pour chaque segment. Les analyses statistiques ont permis de découvrir qu'un plus grand IEP était associé à un plus grand IOA, ce qui indique que l'ombragé créé par les arbres était partiellement responsable dans la diminution de l'usure des fissures, des ornières, du creusement et des autres dommages. En utilisant les relations observées entre l'IEP et l'IOA, on constate qu'une section de rue non ombragée requiert six interventions de réparation sur 30 ans, tandis qu'une section de rue avec 12 Lagerstroemia indica identiques de 4,4 $\mathrm{m}$ de diamètre de cime requiert cinq interventions de réparation et 2,5 interventions dans le cas d'une section de rue comportant six Celtis sinensis de 13,7 $\mathrm{m}$ de diamètre de cime. Lombrage projeté par les gros micocouliers a permis une économie de $7,13 \$ / \mathrm{m}^{2}$ sur une période 30 ans par rapport à une rue non ombragée.

Zusammenfassung. In Modesto, Kalifornien wurden 48 Straßensegmente geteilt in 24 hoch- und niedrigbeschattete Paare. Es wurden Felddaten gesammelt, um einen BürgersteigKonditions-Index (PCI) und einen Baumschattenindex (TSI) für jedes Segment zu kalkulieren. Die statistische Analyse ergab, dass ein großer PCI mit einem großen TSI verbunden war, was bedeutet, dass der Baumschatten teilweise verantwortlich war für ein reduziertes Auftreten von Ermüdungserscheinungen (Rissen) im
Pflaster und anderen Defekten. Unter Anwendung der beobachteten Beziehungen zwischen PCI und TSI erforderten unbeschattete Straßensegmente 6 Deckenerneuerungen über 30 Jahre hinweg, während identische Strassenabschnitte bepflanzt mit 12 Lagerstroemia indica, 4,4 m Kronendurchmesser 5 Deckenerneuerungen erforderten und ein Abschnitt bepflanzt mit 6 Celtis sinensis, $13.7 \mathrm{~m}$ Kronendurchmesser 2,5 Erneuerungen erforderte. Der Schatten von den großen Celtisbäumen wurde mit einer Einsparung über die 30 Jahre von $\$ 7,13 / \mathrm{m}^{2}$ im Vergleich zu unbeschatteten Strassen errechnet.

Resumen. Se equipararon 48 segmentos de calles en 24 pares de sombra alta y baja en Modesto, CA. Se colectaron los datos de campo para calcular el Índice de Condición de Pavimento (PCI, por sus siglas en inglés) y el Índice de Sombra del Árbol (TSI, por sus siglas en inglés) para cada segmento. El análisis estadístico encontró que el mayor PCI estuvo asociado con el mayor TSI, indicando que la sombra del árbol fue parcialmente responsable del reducido agrietamiento, rotura y otros daños por fatiga del pavimento. Utilizando las relaciones observadas entre PCI y TSI, un segmento de calle no sombreada requirió 6 reparaciones en 30 años, mientras otro plantado con 12 Lagerstroemia indica de $4.4 \mathrm{~m}$ (14ft) de diámetro de copa requirió 5 reparaciones, y uno con 6 Celtis sinensis de $13.7 \mathrm{~m}$ ( $45 \mathrm{ft}$ ) de diámetro de copa requirió 2.5 reparaciones. Se hizo una proyección para encontrar que la sombra de los grandes celtis permite ahorrar $\$ 7.13 / \mathrm{m}^{2}$ ( $\$ 0.66 / \mathrm{ft} 2$ ) en un período de 30 años, comparado con calles no sombreadas. 